University of the District of Columbia School of Law

Digital Commons @ UDC Law

$11-5-2020$

\title{
Echoes of 9/11: Rhetorical Analysis of Presidential Statements in the "War on Terror"
}

Bruce Ching

University of the District of Columbia David A Clarke School of Law, bruce.ching@udc.edu

Follow this and additional works at: https://digitalcommons.law.udc.edu/fac_journal_articles

Part of the Immigration Law Commons, National Security Law Commons, and the President/Executive Department Commons

\section{Recommended Citation}

Seton Hall L. Rev. 431, 2020

This Article is brought to you for free and open access by the Publications at Digital Commons @ UDC Law. It has been accepted for inclusion in Journal Articles by an authorized administrator of Digital Commons @ UDC Law. For more information, please contact lawlibraryhelp@udc.edu. 


\title{
Echoes of 9/11: Rhetorical Analysis of Presidential Statements in the "War on Terror"
}

\begin{abstract}
Bruce Ching*
This article examines persuasive statements by Presidents George W. Bush, Barack Obama, and Donald Trump involving appeals to national identity as a rhetorical foundation for anti-terrorism policy since 9/11. Their specific rhetorical methods have included the use of memorable catchphrases, alliteration, metaphorical framing, and contrast between values of the United States and those of the terrorists. President Bush focused on rallying the nation's response against the perpetrators of the 9/11 attacks, identifying the U.S. with "freedom itself" and invoking the phrase "War on Terror." President Obama emphasized the importance of the nation's values while denouncing the Bush administration's torture of terrorism suspects and extolling American values when announcing that U.S. forces killed Osama bin Laden, the leader of the terrorists involved in the 9/11 attacks. In contrast to his predecessors, who explicitly stated that the U.S. was not at war with Islam, President Trump has tended to invoke anti-Muslim sentiment in his anti-terrorism rhetoric and his immigration policies. The presidential statements presented justifications for the actions of the Chief Executives and reflected their priorities in directing the "War on Terror."
\end{abstract}

I. INTRODUCTION 432

II. FUNDAMENTAL ASPECTS OF RHETORIC, TERRORISM AND POLITICAL VIOLENCE,

AND THE 9/11 TERRORIST ATTACKS. 433

A. Rhetoric: The Art of Persuasion. 433

B. Terrorism: Violence as Political Tactic 434

\footnotetext{
${ }^{*}$ Senior Faculty Fellow, Syracuse University College of Law. B.A., University of MissouriSt. Louis; M.A. and J.D., University of Michigan. I am grateful for the suggestions and support of professors Deborah Borman, Diana Coetzee, Christine Coughlin, Jane Cross, David Driesen, Lauryn Gouldin, and Suzanne Rowe. In addition, I appreciate the Michigan State University College of Law summer faculty workshop, the staff of the John F. Schaefer Law Library at the Michigan State University College of Law, the staff of the Syracuse University College of Law Library (especially Kimberly Wilson), and the Legal Writing Institute Sirico Scholars Workshop. I also thank my research assistants, Sohela Suri, Travis Talerico, and Sarah Thomas.
} 
C. The 9/11 Terrorist Attacks

III. STATEMENTS BY GEORGE W. BUSH

A. Same-Day Responses to the 9/11 Attacks 436

1. Reification of Freedom, Reinforcing National Identity. 437

2. Strategic Use of Passive Voice

3. Metaphorical Depiction of National Resolve.

B. "Wanted, Dead or Alive". 440

C. Declaration of "War on Terror". 440

D. "War on Terror" versus "Struggle Against Violent Extremism"

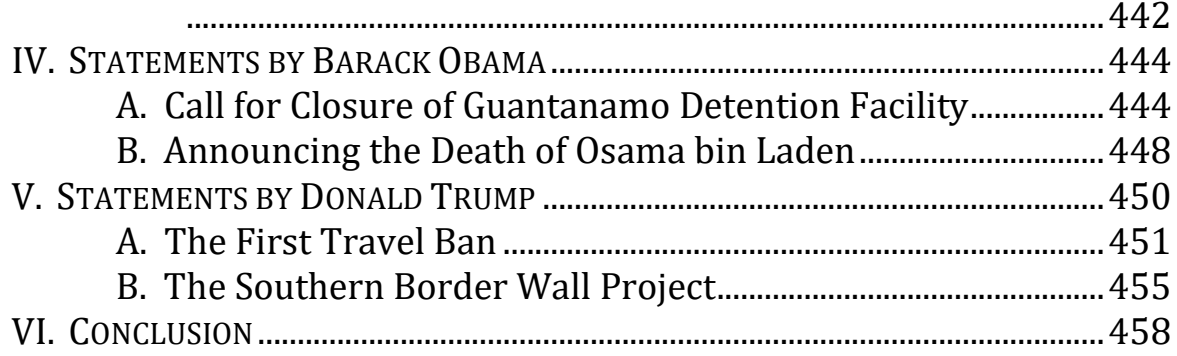

\section{INTRODUCTION}

Al-Qaeda's attacks against the United States on September 11, $2001,(9 / 11)$ comprised the worst terrorist incident in the history of the United States. ${ }^{1}$ Subsequent presidential statements in the "War on Terror" have appealed to values portrayed as fundamental for the national identity of the United States. These narratives employed persuasive methods that the presidents used to justify their actions toward terrorist organizations and suspects. They also provided background for establishing law such as the USA PATRIOT Act, ${ }^{2}$ the operation of military commissions at Guantanamo, ${ }^{3}$ and the prospect of building a wall on the border between the United States and Mexico. ${ }^{4}$

1 See, e.g., Serge Schmemann, U.S. Attacked; President Vows to Exact Punishment for 'Evil,' N.Y. Times (Sept. 12, 2001), https://www.nytimes.com/2001/09/12/us/usattacked-president-vows-to-exact-punishment-for-evil.html; September 11: Photos of the Worst Terrorist Attack on U.S. Soil, History (Sept. 11, 2019), https://www.history.com/news/september-11-attacks-photos.

2 See, e.g., Richard Henry Seamon \& William Dylan Gardner, The Patriot Act and the Wall Between Foreign Intelligence and Law Enforcement, 28 HARV. J.L. \& PuB. PoL'Y 319, 379 (2005) (discussing the Patriot Act's amendments to the Foreign Intelligence Surveillance Act).

3 See, e.g., Judith Resnik, Detention, the War on Terror, and the Federal Courts, 110 Colum. L. Rev. 579, 579 (2010) (mentioning pretrial detention and habeas corpus claims in post-9/11 proceedings related to terrorism, including those at Guantanamo).

4 Terence M. Garrett, Where There's a Wall There's a Way: The End (?) of Democratic Discourse Regarding Immigration and Border Security Policy, 33 MD. J. INT'L L. 183, 187 
This paper explores the rhetorical techniques that contributed to the effectiveness of the presidential statements and considers when changes might have made some of the statements more effective. To stay within a manageable scope of discussion, this article focuses primarily on statements made by the presidents themselves, except when background is needed from the political campaign leading up to a president's election or from other sources within a president's administration.

Part II of this article begins by laying a foundation regarding rhetoric and terrorism, especially concerning the 9/11 attacks. Parts III, IV, and $\mathrm{V}$ explore in detail the rhetorical impacts of statements by Presidents George W. Bush, Barack Obama, and Donald Trump, respectively. Part VI concludes the article by noting recurring themes and rhetorical tactics used by each of these presidents.

\section{Fundamental Aspects of Rhetoric, Terrorism and Political VIOLENCE, AND THE 9/11 TERRORIST ATTACKS}

This Section provides background on rhetoric, terrorism, and the 9/11 attacks. Thus, this Section serves as context for the subsequent sections, which examine how Presidents Bush, Obama, and Trump used specific rhetorical methods of invoking national identity to depict opposition between U.S. values and those of the terrorists.

\section{A. Rhetoric: The Art of Persuasion}

Rhetoric is the art of persuasion. ${ }^{5}$ Classical rhetoric from the time of Aristotle divided rhetorical strategies into three major categories: logos, persuasion based on logic and reason; ethos, persuasion based on the communicator's credibility; and pathos, persuasion based on the emotional component of the communication. ${ }^{6}$ This paper examines the use of linguistic techniques that enhanced the rhetorical effect of presidential statements on terrorism, beginning with responses to the 9/11 attacks and continuing to the present time. These techniques include alliteration, the repetition of initial sounds in words that are closely grouped; ${ }^{7}$ anaphora, the repetition of a word or phrase at the

(2018); Kathy Gilsinan, Trump Keeps Invoking Terrorism to Get His Border Wall, ATLAnTiC (Dec. 11, 2018), https://www.theatlantic.com/international/archive/2018/12/trumpincorrectly-links-immigration-terrorism/576358.

5 Michael R. Smith, Advanced Legal Writing: Theories and Strategies in Persuasive WRITING 11 (3d ed. 2013).

6 Id. at 12.

7 Id. at 312. See Patrick Barry, Alliteration, Restraint, and a Mind at Work, 26(2) Persps.: Teaching Legal Res. \& Writing 73 (2018), for a discussion of the use and overuse of alliteration in law and politics. 
start of consecutive clauses or sentences; 8 strategic choices of which words and expressions to use; ${ }^{9}$ meter, the pattern of stressed and unstressed syllables in a statement; ${ }^{10}$ strategic choice of using the active voice or passive voice; ${ }^{11}$ parallelism in the structure of phrases grouped together; ${ }^{12}$ and repetition of key words or phrases throughout a passage.

\section{B. Terrorism: Violence as Political Tactic}

Terrorism features violence as a means of political coercion. Thus, in defining both "international terrorism" and "domestic terrorism," the definitions section of the federal terrorism statute addresses actions that "appear to be intended-(i) to intimidate or coerce a civilian population; (ii) to influence the policy of a government by intimidation or coercion; or (iii) to affect the conduct of a government by mass destruction, assassination, or kidnapping."13 Al-Qaeda-which eventually orchestrated and carried out the 9/11 attacks on the World Trade Center, the Pentagon, and an unknown additional target that the attackers did not reach ${ }^{14}$ - has been on the United States Department of State's list of Foreign Terrorist Organizations since 1999 (under the name "al-Qua'ida"). ${ }^{15}$

\section{The 9/11 Terrorist Attacks}

On the morning of September 11, 2001, nineteen hijackers commandeered four commercial flights that had recently taken off from the east coast, en route to California. ${ }^{16}$ In New York City, hijacked

8 See Ward Farnsworth, Farnsworth's Classical English RhEToric, 16-18 (1st ed. 2010); see also SMITH, supra note 5, at 329.

9 See, e.g., Peter Murray, Basic Trial Advocacy 65 (1995).

10 For basic discussion of metrical patterns, see Meter, LiterARY DEVICES: DEFINITIONS \& EXAMPLES OF LITERARY TERMS, https://literarydevices.net/meter/ (last visited Jan. 30, 2019).

11 See, e.g., Joan Malmud Rocklin et al., An Advocate Persuades 204-05 (2016).

12 See, e.g., Suzette Haden Elgin, BusinessSpeak: Using the Gentle Art of Verbal Persuasion to Get What You Want at Work 203-06 (1995).

1318 U.S.C. $\S 2331(1)(B)$ (defining international terrorism); 18 U.S.C. $§ ~ 2331(5)(B)$ (defining domestic terrorism).

14 September 11 Attacks, HistoRy (Aug. 25, 2018), https://www.history.com/topics/ 21st-century/9-11-attacks.

15 U.S. DEP'T OF STATE, Foreign Terrorist Organizations, https://www.state.gov/j/ct/ rls/other/des/123085.htm (last visited Sept. 1, 2019). For further discussion of definitions of "terrorism" in federal statutes and agencies, see Nicholas J. Perry, The Numerous Federal Legal Definitions of Terrorism: The Problem of Too Many Grails, 30 J. LEGIS. 249 (2004).

16 September 11 Terror Attacks Fast Facts, CNN, https://www.cnn.com/2013/07/ 27/us/september-11-anniversary-fast-facts/index.html (last updated Nov. 13, 2019). 
airplanes flew into the north and south towers of the World Trade Center at 8:46 AM and 9:03 AM, respectively. ${ }^{17}$ Burning jet fuel from the planes weakened the steel supports for both towers, ${ }^{18}$ and approximately 200 people jumped or fell to their deaths from the upper floors of the towers. ${ }^{19}$ At 9:37 AM, hijackers flew a third plane into the Pentagon, ${ }^{20}$ the headquarters of the U.S. military in Washington, D.C. ${ }^{21}$ The World Trade Center's south tower fell to the ground at 9:59 AM, followed by the collapse of the north tower at 10:28 AM.22 A total of 2,996 people died in the incidents, including 2,763 at the World Trade Center towers. ${ }^{23}$ The final hijacked flight crashed "in a field near Shanksville, Pennsylvania" at 10:03 AM,24 apparently after an altercation between passengers and hijackers. ${ }^{25}$ In response to the news of hijacked planes being used as weapons, at 9:25 AM, the Federal Aviation Administration "initiated a national ground stop, which forbids takeoffs and requires planes in the air to get down as soon as reasonable." 26

The next day, a British newspaper metaphorically declared that "America began pulling up the drawbridges within minutes of the Pentagon attack." 27 The same source also observed that "as fears of further attacks spread, public buildings across the country were also evacuated as the government began shutting down national landmarks, including the Washington Monument, the Statue of Liberty and the St. Louis Gateway Arch. Even Disneyworld in Orlando closed its doors." 28

17 Id.

18 September 11 Attacks, supra note 14.

19 Kevin Flynn \& Jim Dwyer, Falling Bodies, a 9/11 Image Etched in Pain, N.Y. Times (Sept. 10, 2004), https://www.nytimes.com/2004/09/10/nyregion/nyregionspecial2/ falling-bodies-a-911-image-etched-in-pain.html. Some controversy has persisted as to whether victims who fell from the World Trade World Trade Center towers deliberately jumped to avoid being burned alive, or if they fell inadvertently. Id.; Melissa Whitworth, 9/11: 'Jumpers' from the World Trade Center Still Provoke Impassioned Debate, TELEGRAPH (Sept. 3, 2011, 7:30 AM), https://www.telegraph.co.uk/news/worldnews/september11-attacks/8737671/911-Jumpers-from-the-World-Trade-Center-still-provokeimpassioned-debate.html.

20 September 11 Attacks, supra note 14.

21 Id.

22 September 11 Terror Attacks Fast Facts, supra note 16.

23 September 11 Attacks, supra note 14.

24 September 11 Terror Attacks Fast Facts, supra note 16.

25 September 11 Attacks, supra note 14.

26 Sally Donnelly, The Day the FAA Stopped the World, Time (Sept. 14, 2001), http://content.time.com/time/nation/article/0,8599,174912,00.html.

27 Julian Borger, Duncan Campbell \& Charlie Porter, 9/11: Three Hours of Terror and Chaos that Brought a Nation to a Halt, GuARDian (Sept. 12, 2001), https://www.the guardian.com/world/2001/sep/12/september11-usa.

28 Id. 
Al-Qaeda leader Osama bin Laden initially denied involvement in the attacks. ${ }^{29}$ But in late 2001 the U.S. Department of Defense released video of bin Laden retroactively discussing the planning of the attacks and their success. ${ }^{30}$ In 2004, bin Laden did claim responsibility for the 9/11 attacks and threatened additional incidents if the United States did not change its policies; ${ }^{31}$ his previously stated grievances included U.S. support for Israel and U.S. military presence in Arab countries. ${ }^{32}$

\section{STATEMENTS BY GEORGE W. BuSH}

The 9/11 attacks occurred in the first year of George W. Bush's presidency. ${ }^{33}$ This Part examines a series of public statements that Bush delivered to rally the nation's resolve, both during September 11 itself and in the following days and weeks. The Part concludes by exploring the Bush administration's conflicting depictions of the nature of the ongoing clash with al-Qaeda months later, in the absence of any decisive victory.

\section{A. Same-Day Responses to the 9/11 Attacks}

Bush delivered three speeches on September 11, 2001. ${ }^{34}$ The first speech briefly announced that an apparent terrorist attack had struck the World Trade Center, pledged help for the victims, and promised investigation to find those responsible for the attack. ${ }^{35}$ The following

29 Bin Laden Says He Wasn't Behind Attacks, CNN (Sept. 17, 2001, 11:21 AM), http://edition.cnn.com/2001/US/09/16/inv.binladen.denial/index.html.

30 Jessica Hodgson, US Releases Bin Laden Tape, GuARDian (Dec. 13, 2001, 3:49 PM), https://www.theguardian.com/media/2001/dec/13/terrorismandthemedia.broadcas ting.

31 Bin Laden Claims Responsibility for 9/11, CBC NEws (OCT. 29, 2004, 4:08 PM), https://www.cbc.ca/news/world/bin-laden-claims-responsibility-for-9-11-1.513654.

32 See, e.g., Full Text: bin Laden's 'Letter to America,' Guardian (Nov. 24, 2002, 7:07 AM), https://www.theguardian.com/world/2002/nov/24/theobserver.

33 Bush's first presidential inauguration occurred on January 20, 2001. See, e.g., George W. Bush, First Inaugural Address (Jan. 20, 2001) in Online Speech Bank, AMERICAN RHETORIC, https://www.americanrhetoric.com/speeches/gwbfirstinaugural.htm.

34 For a list of the speeches with links to text and video, see Online Speech Bank, AMERICAN RHETORIC, https://www.americanrhetoric.com/gwbushspeeches.htm (last visited Jan. 30, 2020).

35 George W. Bush, Remarks at Emma Booker Elementary School (Sept. 11, 2001) in Online Speech Bank, AMERICAN RHETORIC, https://www.americanrhetoric.com/speeches/ gwbush911florida.htm. Some commentators have compared and contrasted this first 9/11 speech with President Franklin D. Roosevelt's address to Congress following Japan's attack on Pearl Harbor, based on the presidents' rhetorical goals and the circumstances of the attacks. See, e.g., Marvin K. L. Ching, Initial Presidential Speeches on the Dec. 7, 1941, and Sept. 11, 2001, Attacks: A Linguistic/Rhetorical Analysis, S. J. LiNGUISTICS, spring/fall 2003, at 1. 
subsections consider the rhetorical tactics used in Bush's second and third speeches.

\section{Reification of Freedom, Reinforcing National Identity}

Bush began the second speech with the spectacular declaration, "Freedom itself was attacked this morning by a faceless coward. And freedom will be defended." 36 In the opening sentence, Bush took the abstract term "freedom," reified ${ }^{37}$ it-referred to freedom as if it were a concrete entity - and identified it with the U.S., the victim of the 9/11 attacks. He thus portrayed the physical attacks on the U.S. as an attack on the core concept of "freedom itself." The second sentence reinforced the identification between freedom and the U.S. George Lakoff has noted that the concept of freedom is central to U.S. national identity, as reflected in the title of his book, Whose Freedom: The Battle Over America's Most Important Idea. ${ }^{38}$ Further commenting on the use of the words “'freedom,' 'free,' and 'liberty,'” Lakoff noted that "George W. Bush, in his second inaugural address, used these words forty-nine times in a twenty-minute speech-every forty-third word. And if you take into account the opposites-'tyranny,' 'dictatorship,' 'slavery,' and so on-as well as associated words like 'democracy,' the proportion rises higher." 39 The start of Bush's second speech delivered on 9/11, and his second inaugural speech, thus built on the strong identification of freedom as a fundamental American value.

\section{Strategic Use of Passive Voice}

Bush effectively used the passive voice 40 in his declaration at the start of his second speech of the day. Conventional wisdom usually advocates using the active voice, which starts a sentence by designating the party who does the action. ${ }^{41}$ A stirring example of repeated use of the active voice occurred in a famous parliamentary speech given by

36 George W. Bush, 9/11 Remarks at Barksdale Air Force Base (Sept. 11, 2001) in Online Speech Bank, AMERICAN RHETORIC, https://www.americanrhetoric.com/speeches/ gwbush911barksdale.htm.

37 Reify, MERRIAM-WEBSTER, https://www.merriam-webster.com/dictionary/reify (last visited Jan. 30, 2020).

38 George Lakoff, Whose Freedom: The Battle Over America's Most Important Idea (2006).

39 Id. at 5-6.

40 For a general discussion of the active voice and passive voice in legal writing, see, e.g., RocKLIN ET AL., supra note 11 at 204-05.

41 Id.; Bryan A. Garner, Legal Writing in Plain English: A TeXt with Exercises 36 (2d ed. 2013). 
British Prime Minister Winston Churchill to rally his people's resolve against the prospect of a German invasion of Britain in World War II:

[W] shall not flag or fail. We shall go on to the end, we shall fight in France, we shall fight on the seas and oceans, we shall fight with growing confidence and growing strength in the air, we shall defend our Island, whatever the cost may be, we shall fight on the beaches, we shall fight on the landing grounds, we shall fight in the fields and in the streets, we shall fight in the hills; we shall never surrender. ... 42

But the passive voice, which places the action's recipient at the start of a sentence, can be a good strategic choice under some circumstances. ${ }^{43}$

Particularly appropriate situations for using the passive voice occur when the party who commits an action is unknown, or when the speaker wishes to de-emphasize the identity of that party. ${ }^{44}$ The unknown identity of the actor fits the circumstances of Bush's speech; no one had yet claimed responsibility for the 9/11 attacks. ${ }^{45}$ Still, the absence of information about the party who carried out the attacks did not compel the use of the passive voice-Bush could instead have used the active voice to convey that "[a] faceless coward attacked freedom itself this morning."

Nevertheless, the arrangement that Bush used is more effective because the beginning and the end of a unit of meaning-such as a sentence-constitute positions of emphasis for the audience's attention. ${ }^{46}$ The use of these positions of emphasis correlates with the

42 Winston Churchill, We Shall Fight on the Beaches (June 4, 1940) in Speeches, INT'L CHuRchill Soc'Y, https://winstonchurchill.org/resources/speeches/1940-the-finesthour/we-shall-fight-on-the-beaches. Part of the effectiveness of Churchill's exhortation arose from his repetition of the phrase "we shall fight" at the start of most clauses in the passage. In classical rhetoric, the repetition of a word or phrase at the start of successive clauses is known as anaphora. See, e.g., FARNSWORTH, supra note 8 at 16-18 (1st ed. 2010); see also SMITH, supra note 5, at 329. An anaphora can be effective because of "a hammering effect; the repeated language is certain to be noticed, likely to be remembered, and readily conveys strong feeling" and because the repetition creates a rhythmic expectation that can be either fulfilled or disrupted. WARD FARNSWORTH, FARNSWORTH's CLASSICAL ENGLISH RHETORIC, 16 (1st ed. 2010). The anaphora of "we shall fight" in Churchill's speech also displays the sense of determination that Farnsworth noted in commenting on another of Churchill's World War II speeches: "Churchill's anaphora of future action-we shall, we shall, we shall-creates a sense of resolution that underscores the substance of what he is saying." Id. at 17.

43 RocKLIN ET AL., supra note 11 at 205, 294.

44 Id.

45 No one claimed responsibility for the attacks until bin Laden did so in 2004. See Bin Laden Claims Responsibility for 9/11, supra note 31.

46 See, e.g., Mary Beth Beazley, A Practical Guide to Appellate Advocacy 213, 223-24 (3d ed. 2010); Laurel Currie Oates et Al., The Legal Writing Handbook 308 (7th ed. 2018). 
psychological effects of primacy and recency. The primacy effect is invoked to explain that information introduced first has the strongest influence on decision makers; conversely, the recency effect is invoked to explain when information introduced last has the strongest influence on decision makers. ${ }^{47}$ By contrast, information introduced in the middle does not have as much influence as information presented at the start or the conclusion. ${ }^{48}$

By starting the speech with the phrase "freedom itself," Bush emphasized the framework of values in the conflict between the United States and its then-unknown assailant. Placing "[f]reedom itself" and "a faceless coward" as bookends for the first sentence set a stark rhetorical contrast between the United States (identified with the value of freedom) and the party that committed the attacks (identified with the despicable trait of cowardice). The phrase "this morning" was background information rather than an item of primary importance and was therefore de-emphasized by being placed in the middle of the sentence.

\section{Metaphorical Depiction of National Resolve.}

In his third speech of the day, Bush employed a metaphor depicting the resolve of the nation as more enduring than the buildings that were the targets of the terrorist attacks. ${ }^{49}$ Commending the nation's commitment to withstand the events of $9 / 11$, Bush proclaimed that "[t]errorist attacks can shake the foundations of our biggest buildings, but they cannot touch the foundation of America. These acts shatter steel, but they cannot dent the steel of American resolve."50 His statement thus depicted the nation's philosophical foundation as deeper than the physical base of the skyscrapers that fell, and stronger than the material that braced the structures of those buildings. His use of the

47 Mark Spottswood, Ordering Proof: Beyond Adversarial and Inquisitorial Trial Structures, 83 TENN. L. REv. 291, 307-08 (2015).

$48 I d$. at 308. Thus, in the context of voir dire of a jury panel, a practice manual for trial attorneys observes that primacy and recency effects indicate that "jurors will remember the first and last things you say more clearly than everything in between, you have the opportunity to use this information to your advantage in voir dire. Make your first and last statements to the jury panel things you want them to remember about your case." Lisa Blue \& Robert B. HirschHorn, 1 Blue's Guide to Jury SElection § 14:3 (Supp. 2016).

49 Metaphor consists of implicit and figurative comparison between two items. See, e.g., Sмітн, supra note 5, at 197-98. Thus, First Amendment jurisprudence on keeping government uninvolved in religion often invokes a metaphorical reference to the "wall of separation" between church and state. Id. at 205.

50 George W. Bush, 9/11 Address to the Nation (Sept. 11, 2001) in Online Speech Bank, AMERICAN RHETORIC, https://www.americanrhetoric.com/speeches/gwbush911 addresstothenation.htm. 
same words-"foundation(s)" and "steel" - draws a closer comparison and contrast between the physical structures and the national resolve than if he had used different terms for each.

\section{B. "Wanted, Dead or Alive"}

On September 17, 2001, Bush commented on the search for alQaeda's leader, Osama bin Laden, as "a prime suspect" in connection with the 9/11 attacks.51 In response to reporters' questions, Bush deliberately invoked an ethos of the Wild West by twice using the phrase "Wanted, Dead or Alive." 52 First, in response to the question of "Do you want bin Laden dead?," Bush declared, "I want justice. And there's an old poster out west, that I recall, that said, 'Wanted, Dead or Alive.'”53 At the end of the session, in response to a question for clarification, he reiterated the theme:

Just remember, all I'm doing is remembering when I was [a] kid. I remember that I used to put out there in the old West a 'wanted' posted [sic]. It said, "Wanted, Dead or Alive." All I want and America wants is to see them brought to justice. That's what we want. ${ }^{54}$

Thus, Bush's framing of the search for bin Laden looked back to a previous era of "frontier justice" in the Wild West,55 which a commentator has characterized as a time of "rugged individualism ... where there was no rule of law and each man was for himself," 56 and which has been treated as critical to the nation's identity. ${ }^{57}$

\section{Declaration of "War on Terror"}

In addressing a joint session of Congress on September 20, 2001, Bush proclaimed, "Our war on terror begins with al Qaeda, but it does not end there. It will not end until every terrorist group of global reach

51 Text: Bush on Bringing bin Laden to Justice, WASH. Post (Sept. 17, 2001), http://www.washingtonpost.com/wp-srv/nation/attacked/transcripts/bush09

1701.html.

52 Id.

53 Id.

54 Id.

55 Erin McCarthy, Justice, in Collateral Language: A User's Guide to America's New WAR 128-29 (John Collins \& Ross Glover eds., 2002).

56 Simcha Herzog, Constitutional Problems Posed by Aviation Security Post September Eleventh, 6 Fla. COASTAL L. REV. 361, 391 (2005).

57 Thus, in criticizing misappropriation of Native American figures in sports, Professor Jeffrey S. Miller commented that "Native American images used by sports teams are fueled by an American identity built on the myth of the Wild West." Jeffrey S. Miller, Native American Athletes: Why Gambling on the Future is a Sure Bet, 4 VA. SPORTS \& ENT. L.J. 239, 250 n.62 (2005). 
has been found, stopped, and defeated."58 The "War on Terror" label followed in the footsteps of previous presidents declaring war on large societal problems - in particular, Lyndon Johnson's announcement of a "War on Poverty" in the 1960s59 and Richard Nixon's statement of a war on drugs in the 1970s.60

The declaration of "War on Terror" was a rhetorical focus for the national sentiment soon after 9/11. In polling that was "conducted Sept. 21-22, 89\% of Americans [said] the United States should take military action in retaliation for the terrorist attacks on Sept. 11, while just 7\% disagree[d]."61

Critics warned that declaring "War on Terror" justified protracted and overbroad action by the administration. For example, Professor Katie Rose Guest stated that "Bush declared war on an emotion'intense fear' - that has always and will always exist ('Terror').... By declaring war on terror, America's enemy became ephemeral and eternal."62 Similarly, George Lakoff stressed that "declaring a 'war on terror' against an elusive and amorphous enemy gave President Bush special war powers that could be extended and used indefinitely, even against American citizens."63

58 George W. Bush, Address to Joint Session of Congress Following 9/11 Attacks (Sept. 20, 2001) in Online Speech Bank, AMERICAN RHETORIC, https://www.american rhetoric.com/speeches/gwbush911jointsessionspeech.htm.

59 Lyndon Baines Johnson, First State of the Union Address (January 8, 1964) in Online Speech Bank, AMERICAN RHETORIC, http://www.americanrhetoric.com/speeches/ lbj1964stateoftheunion.htm ("This administration today, here and now, declares unconditional war on poverty in America.").

60 Remarks about an Intensified Program for Drug Abuse Prevention and Control, AMERICAN PRESIDENCY PRojeCT, https://www.presidency.ucsb.edu/documents/remarksabout-intensified-program-for-drug-abuse-prevention-and-control ("America's public enemy number one in the United States is drug abuse. In order to fight and defeat this enemy, it is necessary to wage a new, all-out offensive."). "The 'war on drugs' was a term coined by the press in 1971 after President Richard Nixon held a press conference to publicize the growing menace of narcotics flooding the country." Chris Summers, Heroin Now Kills More People Than Guns: Drugs Overdoses Claimed 50,000 Lives in the US Last Year, DAILY MAIL (Dec. 8, 2016) https://www.dailymail.co.uk/news/article-4015536/Agrim-tally-soars-More-50-000-overdose-deaths-US.html.

61 David W. Moore, Support for War on Terrorism Rivals Support for WWII, GaLLUP (Oct. 3, 2001), https://news.gallup.com/poll/4954/support-war-terrorism-rivalssupport-wwii.aspx is correct.

62 Katie Rose Guest, The Ideology of Terror: Why We Will Never Win the "War," 28 J. AM. Culture 368 (2005).

63 LAKOFF, supra note 38 , at 11. 


\section{D. "War on Terror" versus "Struggle Against Violent Extremism"}

Despite Bush's earlier use of the phrase "Wanted, Dead or Alive" regarding Osama bin Laden within a week after $9 / 11,64$ bin Laden evaded U.S. forces throughout Bush's presidency. ${ }^{65}$ In fact, just a few months after 9/11-on March 13, 2002, in response to a reporter's question about whether the U.S. could be secure without knowing whether bin Laden was dead or alive-President Bush stated that bin Laden was "on the run" and declared that "I truly am not that concerned about him."66

Soon after 9/11, while commenting on approval ratings for two previous conflicts-the Korean War and the Vietnam War-the Gallup News Service noted that approval ratings over time tended to dip when the conflicts became protracted and when military results were not clearly successful. ${ }^{67}$ Perhaps concerned by public perception of a long, drawn-out conflict without clear victory, Bush administration officials by late July 2005 began to abandon the use of the term "War on Terror," replacing it with the phrase, "struggle against violent extremism."68 Secretary of Defense Donald Rumsfeld and other military spokespeople used the new term, which Chairman of the Joint Chiefs of Staff Richard Myers justified by positing that going forward, the effort of the U.S. and its allies would be "more diplomatic, more economic, more political than it is military." 69 George Lakoff suggested that although "[t]he war frame is all-consuming" in that it displaces attention from domestic problems, the administration nevertheless shifted to a different frame by deliberately employing a non-memorable phrase, "struggle against violent extremism," because it would not highlight "the failure of the president's war policy" - in contrast to "the war frame [that] includes

64 Text: Bush on Bringing bin Laden to Justice, WASH. Post (Sep. 17, 2001), http://www.washingtonpost.com/wp-srv/nation/attacked/transcripts/bush09 1701.html.

65 U.S. forces did not catch up with bin Laden until May 1, 2011, when President Obama gave the order to execute a raid that resulted in bin Laden's death. See Macon Phillips, Osama Bin Laden Dead, OBAma White House Archives (May 2, 2011, 12:16 AM), https://www.whitehouse.gov/blog/2011/05/02/osama-bin-laden-dead.

66 Bush Talks of Threats, Concerns, and U.S. Judges, CNN (Mar. 14, 2002, 3:14 AM), http://www.cnn.com/2002/ALLPOLITICS/03/13/Bush.news.conference/; see also Mugsys Rapsheet, Bush: Truly Not Concerned about bin Laden (Long Version), YouTuBE (Aug. 3, 2008), https://www.youtube.com/watch?v=FPTwsMEiI0g.

67 Moore, supra note 61.

68 See, e.g., Eric Schmitt \& Thom Shanker, U.S. Officials Retool Slogan for Terror War, N.Y. Times (July 26, 2005), https://www.nytimes.com/2005/07/26/politics/usofficials-retool-slogan-for-terror-war.html.

69 Id. Thus, Myers embedded anaphora within a tricolon-repeating the same word at the start of successive phrases, as part of presenting a group of three items-in asserting alternatives to military action. 
an end to the war-winning the war, mission accomplished!"70 Moreover, although apparently unmentioned by commentators, the arrangement of words in the phrase "struggle against violent extremism" formed a nice little acronym-SAVE. By contrast, the name of the USA PATRIOT Act includes a very strained acronym, standing for Uniting and Strengthening America by Providing Appropriate Tools Required to Intercept and Obstruct Terrorism Act. ${ }^{71}$

But, on August 3, 2005-just weeks after the administration's shift toward the term "struggle against violent extremism"-Bush delivered a speech in which he "publicly overruled some of his top advisers ... in a debate about what to call the conflict with Islamic extremists"; in that speech, he "used the phrase 'war on terror' no less than five times." 72 Professor Mary Ellen O'Connell suggested a motive for Bush's insistence on maintaining the label of "war on terror," when she observed that "[w]ithout a war, there could be no wartime privileges to kill, detain without trial, and try without peacetime due process." 73

70 George Lakoff, "War on Terror," Rest In Peace, Rockridge Institute Writings, https://georgelakoff.files.wordpress.com/2011/03/2006-war-on-terror-rest-inpeace.doc (last updated Feb. 28, 2006).

71 See USA PATRIOT Act of 2001, 107 Pub. L. 56, 115 Stat. 272. As noted by Professor Susan N. Herman, among the Patriot Act's more controversial surveillance provisions are executive authority to obtain records and tangible items without preliminary judicial approval; the ability to compel "internet service providers and other custodians" to provide records of their customers without a court order; expansion of authority for surveillance under the Foreign Intelligence Surveillance Act; and ''sneak and peak' authority" allowing delay in notification that a search warrant has been executed. Susan N. Herman, The USA Patriot Act and the Submajoritarian Fourth Amendment, 41 Harv. C.R.-C.L. L. REV. 67, 73-74 (2006). Herman observes that those provisions run contrary to Fourth Amendment norms that prohibit unreasonable search and seizure. Id. at 74 .

72 Richard W. Stevenson, President Makes It Clear: Phrase Is 'War on Terror,' N.Y. Times (Aug. 4, 2005), https://www.nytimes.com/2005/08/04/politics/presidentmakes-it-clear-phrase-is-war-on-terror.html. Nevertheless, by early December 2006, the Foreign Office of U.S. ally Britain advised British government officials to stop using the phrase "War on Terror," because of that term's likelihood of alienating Muslims in Britain and in Islamic countries. Jason Burke, Britain Stops Talk of 'War on Terror,' GUARDIAN (Dec. 9, 2006, 7:11 PM), https://www.theguardian.com/politics/2006/dec/ 10/uk.terrorism. On April 16, 2007, Britain's International Development Secretary formally announced abandonment of Britain's use of the phrase "War on Terror," explaining that, "In the UK, we do not use the phrase 'war on terror' because we can't win by military means alone, and because this isn't us against one organized enemy with a clear identity and a coherent set of objectives." Benn Criticizes 'War on Terror' Idea, GUARDIAN (Apr. 16, 2007, 3:00 PM), https://www.theguardian.com/world/2007/apr/ 16/terrorism.iraq.

73 Mary Ellen O'Connell, When Is a War Not a War? The Myth of the Global War on Terror, 12 ILSA J. INT'L \& CoMP. L. 535, 539 (2006). 


\section{STATEMENTS BY BARACK OBAMA}

This Part examines rhetorical methods that President Obama used in calling for closure of the Guantanamo Bay detention camp and in announcing the death of Osama bin Laden, who had led al-Qaeda's 9/11 attacks against the U.S.

\section{A. Call for Closure of Guantanamo Detention Facility}

Soon after taking office as President, Barack Obama issued an executive order on January 22, 2009, to close the detention center at Guantanamo Bay. ${ }^{74}$ On May 21, 2009, Obama delivered a speech on national security; his speech included a call for Congress to cooperate with efforts to close the detention facility. ${ }^{75}$ Obama emphasized the power of moral values as a source of U.S. strength by declaring: "I believe with every fiber of my being that in the long run we also cannot keep this country safe unless we enlist the power of our most fundamental values." 76 He designated those fundamental values as "the foundation of liberty and justice in this country" as reflected in the Declaration of Independence and the Constitution's Bill of Rights. ${ }^{77}$

In the next few paragraphs of his speech, Obama repeatedly mentioned U.S. morality and values:

I make this claim not simply as a matter of idealism. We uphold our most cherished values not only because doing so is right, but because it strengthens our country and it keeps us safe. Time and again, our values have been our best national security asset-in war and peace; in times of ease and in eras of upheaval.

Fidelity to our values is the reason why the United States of America grew from a small string of colonies under the writ of an empire to the strongest nation in the world.

It's the reason why enemy soldiers have surrendered to us in battle, knowing they'd receive better treatment from America's Armed Forces than from their own government.

74 Exec. Order No. 13492, 74 Fed. Reg. 4897 (Jan. 22, 2009).

75 Remarks by the President on National Security, 5-21-09, OBAma White House ARCHIVEs (May 21, 2009), https://obamawhitehouse.archives.gov/the-press-office/ remarks-president-national-security-5-21-09.

76 Id.

77 Id. 
It's the reason why America has benefitted from strong alliances that amplified our power, and drawn a sharp, moral contrast with our adversaries. ${ }^{78}$

Obama concluded the section with his proclamation, "It's the reason why we've been able to overpower the iron fist of fascism and outlast the iron curtain of communism, and enlist free nations and free peoples everywhere in the common cause and common effort of liberty."79 The statement employs multiple instances of alliteration:80 fist of fascism, curtain of communism, common cause. As noted by Professor Michael R. Smith, "Alliteration contributes to the euphony of writing. Because of the sound repetition, alliterative writing flows smoothly and melodically." 81 In addition, the repetition of "iron" in consecutive clauses is an anaphora ${ }^{82}$ that stresses the similarity of the content of the clauses-iron fist of fascism and iron curtain of communism. Moreover, in referring to the iron curtain of communism, Obama alluded to Winston Churchill's original use of the term "iron curtain," in which he characterized the Soviet Union's control of Eastern Europe and its isolation from the rest of Europe by declaring that "an iron curtain has descended across the Continent." 83

In the next paragraph, Obama again emphasized how values shape national identity, portraying an ideological battle between the U.S. and the terrorists:

From Europe to the Pacific, we've been the nation that has shut down torture chambers and replaced tyranny with the rule of law. That is who we are. And where terrorists offer only the injustice of disorder and destruction, America must demonstrate that our values and our institutions are more resilient than a hateful ideology. 84

In the first sentence, "[f]rom Europe to the Pacific" might allude to the scope of U.S. involvement in World War II, especially when it followed the allusion to Churchill's post-World War II use of the term "iron curtain" to describe Soviet control of Eastern Europe. In the next

78 Remarks by the President on National Security, 5-21-09, supra note 75 (emphasis added).

79 Id.

80 SMith, supra note 5, at 312 ("Alliteration is most commonly defined as the use of two or more words in close proximity to each other that begin with (or prominently contain) the same letter sound.").

81 Id.

82 See supra note 42 and accompanying text.

83 Churchill Delivers Iron Curtain speech, Histony (Mar. 2, 2010), https://www.history.com/this-day-in-history/churchill-delivers-iron-curtain-speech.

84 Remarks by the President on National Security, 5-21-09, supra note 75. 
sentence, "That is who we are" is an explicit declaration of identity. The final sentence of the passage begins with an alliterative association of terrorists with "disorder and destruction," and concludes by portraying the conflict as a clash pitting "our values and our institutions" against the "hateful ideology" of the terrorists. ${ }^{85}$

Later in the speech, Obama criticized the George W. Bush administration's use of torture for interrogating suspected terrorists. He concluded this section as follows:

Now, I should add, the arguments against these techniques did not originate from my administration. As Senator McCain once said, torture "serves as a great propaganda tool for those who recruit people to fight against us." And even under President Bush, there was recognition among members of his own administration-including a Secretary of State, other senior officials, and many in the military and intelligence community - that those who argued for these tactics were on the wrong side of the debate, and the wrong side of history. That's why we must leave these methods where they belong-in the past. They are not who we are, and they are not America. ${ }^{86}$

Near the end of the passage, Obama made good use of an anaphora ${ }^{87}$ in characterizing advocates of torture as being "on the wrong side of the debate, and the wrong side of history."

The statement at the end-that the torture methods "are not who we are, and they are not America" — stands in contrast to the previouslyquoted passage, in which Obama mentioned "shut[ting] down torture chambers" and declared, "[t]hat is who we are." But he could have made this contrast sharper by placing its components closer together. Obama's statement identifying the U.S. as having closed torture chambers appeared in the fifteenth paragraph of the official transcript, ${ }^{88}$ and his assertion that methods of torture "are not who we are, and they are not America" did not occur until the twenty-second paragraph ${ }^{89}-$ so the contrast probably would not have stood out vividly to the audience that was hearing the speech live, without a written text.

85 President Obama's emphasis on contrasting American values and those of the terrorists who attacked the country bring to mind President Bush's similar contrast of values in his declaration on $9 / 11$ that "[f]reedom itself was attacked by a faceless coward this morning" and the frequent references to freedom as a U.S. value, in contrast to opposite characteristics such as "tyranny." See supra footnotes 33-37 and accompanying text.

86 Remarks by the President on National Security, 5-21-09, supra note 75.

87 See supra note 42 and accompanying text.

88 Remarks by the President on National Security, 5-21-09, supra note 75.

89 Id. 
Video broadcast of the speech confirms the significant time lapse of more than five minutes between the two statements: the proclamation of " $[\mathrm{t}]$ hat is who we are" in closing torture chambers occurred at the 7:10 mark of the speech, while the declaration that torture methods "are not who we are, and they are not America" did not occur until the 12:49 mark. ${ }^{90}$ Rhetorician Suzette Haden Elgin has explained that a passage "will be perceived as awkward when it places an undue burden on the short-term memory of the person at whom the message is aimed." 91 The five-minute interval in Obama's speech, in between the description of practices that help to shape U.S. identity and the description of other practices that are antithetical to U.S. identity, was probably too long to effectuate a striking rhetorical contrast because it would inordinately tax the audience's short-term memory. Therefore, the comparison would probably have been more effective if it occurred within a shorter span, such as two consecutive paragraphs, that would have taken less time to complete. The compression of time for completion is especially important for reaching an audience through television, as sound bites in news coverage have become shorter. For example, a "study of network news coverage of presidential elections found that the average 'sound bite' (the amount of time a candidate is shown speaking) ha[d] shrunk from forty-three seconds in 1968 to nine seconds in 1988."92

But Congressional refusal to take action on transferring the last detainees out from Guantanamo foiled attempts to close the detention facility. ${ }^{93}$ Thus, in the final year of his presidency, Obama noted that " 15 years after $9 / 11-15$ years after the worst terrorist attack in American history-we're still having to defend the existence of a facility and a process where not a single verdict has been reached in those attacksnot a single one." 94

90 The Obama White House, President Obama: Our Security, Our Values, YouTube (May 21, 2009), https://www.youtube.com/watch?v=ic6Sh3zjUF0.

91 ELGIN, supra note 12 at 25.

92 Phyllis Kaniss, Assessing the Role of Local Television News in Elections: Stimulating Involvement or Indifference, 11 YALE L. \& PoL'Y REv. 433, 439 (1993) (citing Daniel C. Hallin, Sound Bite News: Television Coverage of Elections, 1968-1988, 42 J. Comm. 5, 5-6 (1992) and Kiku Adatto, Sound Bite Democracy: Network Evening News Presidential CAmpaign Coverage, 1968 and 1988 (Joan Shorenstein Barone Center for Press, Politics, and Public Policy Research Paper R-2, 1990)); Craig Fehrman, The Incredible Shrinking Sound Bite, BOSTON.COM (Jan. 2, 2011), http://archive.boston.com/bostonglobe/ideas/ articles/2011/01/02/the_incredible_shrinking_sound_bite.

93 See, e.g., David J.R. Frakt, Prisoners of Congress: The Constitutional and Political Clash over Detainees and the Closure of Guantanamo, 74 U. PITT. L. REv. 179 (2012).

94 Remarks by the President on Plan to Close the Prison at Guantanamo Bay, Овама White House ARCHIVES, (Feb. 23, 2016), https://obamawhitehouse.archives.gov/thepress-office/2016/02/23/remarks-president-plan-close-prison-guantanamo-bay. 


\section{B. Announcing the Death of Osama bin Laden}

On May 1, 2011, President Obama announced on television that U.S. forces had killed al-Qaeda leader Osama bin Laden. ${ }^{95}$ The early part of the speech featured several thematic shifts: from recalling the 9/11 attacks and the damage they inflicted, to remembering the resulting losses, to commemorating the immediate national response of coming together, and then noting the further response of seeking justice against those who committed the attacks. ${ }^{96}$ After starting by announcing the death of bin Laden, Obama stated that:

It was nearly 10 years ago that a bright September day was darkened by the worst attack on the American people in our history. The images of $9 / 11$ are seared into our national memory-hijacked planes cutting through a cloudless September sky; the Twin Towers collapsing to the ground; black smoke billowing up from the Pentagon; the wreckage of Flight 93 in Shanksville, Pennsylvania, where the actions of heroic citizens saved even more heartbreak and destruction. ${ }^{97}$

The passage began with an alliterative contrast_-bright September day was darkened"-denoting a change in mood resulting from the 9/11 attacks.

Creating a montage of images of that day, Obama then used a doubly alliterative description, "hijacked planes cutting through a cloudless September sky" - cutting alliterates with cloudless, and September alliterates with sky. Moreover, Obama's effective construction of the phrase depended on his careful use of word choice, which is highlighted if we consider an alternative that would preserve the same meter and alliteration but diminish the impact of the statement-"hijacked planes cruising through a cloudless September sky." Cutting inherently carries a suggestion of violence, and in the context of Obama's statement, it might subtly allude to the box cutters that were reportedly used as weapons by the hijackers when they seized control of the planes; ${ }^{98}$ by contrast, cruising suggests a placid experience

95 For White House transcript and video link, see Macon Phillips, Osama Bin Laden Dead, Овамa White House Archives, (May 2, 2011), https://www.whitehouse.gov/blog/ 2011/05/02/osama-bin-laden-dead.

96 Id.

97 Id.

98 Box Cutters Found on Other September 11 Flights, CNN, (Sept. 24, 2001, 11:35 AM), http://www.cnn.com/2001/US/09/23/inv.investigation.terrorism ("The hijackers who seized the airliners on September 11 had used box cutters to attack some of the crew and passengers, according to government officials and accounts from passengers in-flight who phoned relatives before their planes crashed."). 
that would be inconsistent with the disastrous nature of that day's events.

Obama returned to the rhetorical power of contrast when he invoked the image of "the Twin Towers collapsing to the ground"emphasizing the difference between the lofty height of the World Trade Center towers before the attack and the ground-level rubble after. ${ }^{99}$

A few sentences later, he declared that "[o]n September 11, 2001, in our time of grief, the American people came together. We offered our neighbors a hand, and we offered the wounded our blood."100 The effectiveness of Obama's use of concrete, visceral images is highlighted if we consider a more prosaic alternative, such as "we offered help for our neighbors and medical aid for the wounded." Compared to such a bland restatement, Obama's image of literally extending a hand in offer of help, followed by the reference to blood donations to help the wounded, creates a more powerful impact.

In the same statement, repetition of the phrase "we offered" in consecutive clauses invokes the previously discussed rhetorical device, anaphora. ${ }^{101}$ In addition, Obama's statement uses parallelism in linguistic structure, which can be especially useful to facilitate understanding of oral statements when the audience does not have a written text to examine102_which was the situation for Obama's televised announcement. 103 "We offered our neighbors a hand" uses this sequence: subject, verb, possessive pronoun, indirect object, article, direct object. "[W]e offered the wounded our blood" uses this sequence:

99 In addition, George Lakoff has suggested that personification of the characteristics of the towers contributed to the horror of the attack on the World Trade Center: Buildings are metaphorically people. We see features-eyes, nose, and mouth-in their windows. I now realize that the image of the plane going into South Tower was for me an image of a bullet going through someone's head, the flames pouring from the other side like blood spurting out. It was an assassination. The tower falling was a body falling. The bodies falling were me, relatives, friends. Strangers who had smiled as they passed me on the street screamed as they fell past me. The image afterward was hell: ashes, smoke and steam rising, the building skeleton, darkness, suffering, death.

George LaKoff, Metaphors of Terror, in The All New Don't Think of an Elephant! Know Your Values and Frame the Debate 104 (2014).

100 Osama Bin Laden Dead, supra note 95.

101 See supra note 42 and accompanying text.

102 See ELGIN, supra note 12 at 203.

103 For a video of the announcement, as well as a later-produced text transcription, see Barack Obama, Barack Obama Announces the Death of Osama bin Laden (May 1, 2011), in Online Speech Bank, AMERICAN RHETORIC, https://www.americanrhetoric.com/ speeches/barackobama/barackobamaosamabinladendeath.htm (last updated Nov. 25, 2018). 
subject, verb, article, indirect object, possessive pronoun, direct object. The statement's symmetrical structure reinforces similarity in their content; syntactic similarity reinforces semantic similarity. ${ }^{104}$

Moreover, the two phrases on either side of the conjunction "and"- We offered our neighbors a hand" and "we offered the wounded our blood"-use identical meter (patterns of stressed and unstressed syllables). ${ }^{105}$ The repetition of the metrical pattern creates a rhythmic passage that enhances the statement's rhetorical effectiveness because rhythmically smooth phrasing allows the audience to understand a statement with less effort than required to understand a statement without such rhythm. ${ }^{106}$

\section{STATEMENTS BY DONALD TRUMP}

Donald Trump's rhetorical style has been described as "combative, insulting, self-referential"; 107 moreover, his statements are often misleading or outright untruthful.108 In addition, he frequently contradicts his own previous statements. ${ }^{109}$ Nevertheless, this paper will examine some of his more internally consistent statements. ${ }^{110}$ In particular, this Part considers the rhetoric of Trump's advocacy for the travel ban that was initially aimed at restricting entry to the U.S. from seven Mideastern countries, and of Trump's calls for building a wall along the border between the U.S and Mexico. Both projects were depicted as at least partially justified by the need to keep terrorists from entering the U.S. Many of President Trump's declarations about terrorism are anti-Islamic; this Part will explore them by contrast with

104 See Helene S. Shapo Et Al., Writing And ANAlYSiS In the LAW 174 (4th ed. 1999).

105 For a basic discussion of metrical patterns, see Meter, supra note 10.

106 See SMITH, supra note 5, at 311.

107 Sam Sanders, Data Scientists Find Consistencies in Donald Trump's Erratic Twitter Strategy, NPR (Aug. 18, 2016, 4:28 PM), https://www.npr.org/2016/08/18/490523 985/data-scientists-find-consistencies-in-donald-trumps-erratic-twitter-strategy.

108 See, e.g., Glenn Kessler, Salvador Rizzo \& Meg Kelly, President Trump Made 16,241 False or Misleading Claims in His First Three Years, WASH. Post (Jan. 20, 2020, 3:00 AM), https://www.washingtonpost.com/politics/2020/01/20/president-trump-made16241-false-or-misleading-claims-his-first-three-years/.

109 Thus, Professor Bradley Wendel has stated that "[c]omplicating the analysis of Trump's views on the rule of law is his tendency to exaggerate, play to his base, contradict himself, and speak off the cuff on issues about which he knows very little." W. Bradley Wendel, Government Lawyers in the Trump Administration, 69 HASTINGS L.J. 275, 284 (2017).

110 For a discussion that more directly addresses President Trump's practice of utilizing political insults, such as his use of derogatory names for his political opponents, the dissemination of narratives portraying Trump as exhibiting qualities of a superhero, and how Trump's opponents might effectively counter such tactics, see Cathren Page, $A n$ "Astonishingly Excellent" Solution to Super-Fake Narratives, 58 WASHBURN L.J. 673 (2019). 
statements in which Presidents Bush and Obama distinguished between the 9/11 terrorists and the great majority of Muslims.

Another feature of many of Trump's statements on policy is that they are made through the social medium of Twitter, rather than by more traditional and formal means. ${ }^{111}$ Nevertheless, President Trump's tweets are official statements: On June 6, 2017, then-White House Press Secretary Sean Spicer stated that President Trump's tweets are "official statements by the President of the United States." 112 Moreover, a few months later, on November 13, 2017-in answer to a court's request for clarification on whether President Trump's tweets are official in nature-the Department of Justice indicated in its responsive filing that " $[t]$ he government is treating the [President's tweets, among other declarations] as official statements of the President of the United States."113

\section{A. The First Travel Ban}

One week into his presidency, Trump issued an executive order prohibiting people from several Mideastern, majority-Muslim countries from entering the U.S. The order was framed as a measure to protect vulnerable populations in the U.S. For an overview of the travel ban and its changes, the ACLU of Washington has produced a chronology of all three versions of President Trump's travel ban executive orders, the litigation they triggered and subsequent appeals, and the Supreme Court's decision to uphold the third version of the ban. ${ }^{114}$

111 See Elizabeth Sloan, Social Media and the U.S. Presidency, Media MilwaukEE (Mar. 26, 2019), https://mediamilwaukee.com/top-stories/social-media-and-the-u-spresidency.

112 Elizabeth Landers, White House: Trump's Tweets Are 'Official Statements,' CNN (June 6, 2017, 4:37 PM), https://www.cnn.com/2017/06/06/politics/trump-tweetsofficial-statements/index.html. The White House Press Secretary's designation of President Trump's tweets as official statements has also been mentioned in various law journal articles. See W. Neil Eggleston \& Amanda Elbogen, The Trump Administration and the Breakdown of Intra-Executive Legal Process, 127 YALE L.J. F. 825, 832 n.28 (2018); see also J.B. Ruhl \& James Salzman, Presidential Exit, 67 DukE L.J. 1729, 1741 (2018).

113 Defendants' Supplemental Submission and Further Response to Plaintiffs' PostBriefing Notices at 2, James Madison Project v. Dep't of Justice, 302 F. Supp. 3d 12 (D.D.C. 2018) (No. 1:17-cv-00144-APM), https://assets.documentcloud.org/documents/420 0037/Trump-Twitter-20171113.pdf. The Department of Justice's treatment of President Trump's tweets as official statements has also been mentioned in several law journal articles. See Kathryn E. Kovacs, Rules about Rulemaking and the Rise of the Unitary Executive, 70 ADMin. L. REv. 515, 564 n.410 (2018); see also J. Richard Broughton, The Federal Death Penalty, Trumpism, and Civil Rights Enforcement, 67 Am. U. L. Rev. 1611, 1626 n.61 (2018); Ann M. Murphy, All the President's Privileges, 27 J.L. \& Pol'y 1, 29 n.202 (2018).

114 Timeline of the Muslim Ban, ACLU of WASH., https://aclu-wa.org/pages/timelinemuslim-ban (last visited Jan. 31, 2020). 
On January 27, 2017, President Trump issued his first travel ban, titled "Executive Order Protecting the Nation from Foreign Terrorist Entry into the United States." 115 The order's first paragraph stated its purpose as "to protect the American people from terrorist attacks by foreign nationals admitted to the United States."116 In addition, section 1 set forth a statement of purpose, which concluded by invoking ideals of upholding U.S. law and protecting vulnerable groups within the U.S. as justification for the travel ban:

The United States cannot, and should not, admit those who do not support the Constitution, or those who would place violent ideologies over American law. In addition, the United States should not admit those who engage in acts of bigotry or hatred (including "honor" killings, other forms of violence against women, or the persecution of those who practice religions different from their own) or those who would oppress Americans of any race, gender, or sexual orientation. ${ }^{117}$

The order provided for an immediate 90-day ban on entry into the U.S. by aliens from countries referenced in section 217(a)(12) of the Immigration and Nationality Act, 118 as well as an immediate 120-day ban on all refugee entry into the U.S.119 Oddly, the Executive Order itself did not specifically list the countries from which travel to the U.S. would be prohibited; 120 thus, there was some "initial confusion" about which countries were subject to the ban. ${ }^{121}$ But two days later, on January 29, 2017, the Department of Homeland Security released a "Fact Sheet" specifying that, "For the next 90 days, nearly all travelers, except U.S. citizens, traveling on passports from Iraq, Syria, Sudan, Iran, Somalia, Libya, and Yemen w[ould] be temporarily suspended from entry to the United States." 122 All seven of the listed countries have a majority-

115 Exec. Order No. 13769, 82 Fed. Reg. 8977 (Jan. 27, 2017).

116 Id.

117 Id. at $\S 1$.

118 Id. at $\S 3(\mathrm{c})$.

119 Id. at $\S 5$.

120 But in the context of eligibility for a visa waiver program, the statutory provision mentioned in subsection (c) of the order does specifically address aliens who are not nationals of "Iraq or Syria," 8 U.S.C. § 1187(a)12(A)(ii)(I), and also refers to aliens who are not nationals of countries designated by the Secretary of State or the Secretary of Homeland Security, id. §§ 1187(a)12(A)(ii)(II), (III).

121 Trump's Executive Order on Immigration, Annotated, NPR (Jan. 31, 2017, 10:46 AM), https://www.npr.org/2017/01/31/512439121/trumps-executive-order-onimmigration-annotated.

122 Fact Sheet: Protecting The Nation From Foreign Terrorist Entry To The United States, DeP'T of Homeland SEc. (Jan. 29, 2017), https://www.dhs.gov/news/2017/01/ 29/protecting-nation-foreign-terrorist-entry-united-states. 
Muslim population. ${ }^{123}$ But one of the Executive Order's exceptions provided that a refugee might be admitted "when the person is a religious minority in his country of nationality facing religious persecution." 124 Thus, the ban was designed to discriminate on the basis of religion-in fact, on the same day that he signed the first travel ban order to restrict entry from the list of seven majority-Muslim countries, Trump had an interview with the Christian Broadcasting Network, in which he agreed that "he would prioritize persecuted Christians in the Middle East for admission as refugees."125

The first travel ban's anti-Muslim orientation reflected the antiMuslim rhetoric that was displayed in many of Trump's declarations as a candidate for President. For example, in October and November of 2015, Candidate Trump broached the idea of shutting down mosques in the U.S., apparently in response to news of terrorist attacks abroad.126 At a campaign rally on December 7, 2015, he declared that "Donald J. Trump is calling for a total and complete shutdown of Muslims entering the United States until our country's representatives can figure out what is going on."127 And on March 9, 2016, he opined to a CNN news host, "I think Islam hates us. There's something there that-there's a tremendous hatred there. There's a tremendous hatred. We have to get to the bottom of it. There's an unbelievable hatred of us."128

A study of FBI crime statistics by the Pew Research Center indicated that Trump's anti-Muslim rhetoric correlated strongly with an increase in anti-Muslim assaults, and the increase in such assaults was even greater than the increase in anti-Muslim assaults following the

123 Trump's Executive Order on Immigration, Annotated, supra note 121.

124 Exec. Order No. 13769, 82 Fed. Reg. 8977 § 5(e) (Jan. 27, 2017).

125 Carol Morello, Trump Signs Order Temporarily Halting Admission of Refugees, Promises Priority for Christians, WASH. Post (Jan. 27, 2017), https://www.washington post.com/world/national-security/trump-approves-extreme-vetting-of-refugeespromises-priority-for-christians/2017/01/27/007021a2-e4c7-11e6-a547-5fb9411d 332c_story.html.

126 Jenna Johnson \& Abigail Hauslohner, 'I Think Islam Hates Us': A Timeline of Trump's Comments about Islam and Muslims, WASH. Post (May 20, 2017), https://www.washingtonpost.com/news/post-politics/wp/2017/05/20/i-thinkislam-hates-us-a-timeline-of-trumps-comments-about-islam-and-muslims/.

127 Id.

128 Id.; Theodore Schleifer, Donald Trump: 'I Think Islam Hates Us,' CNN (Mar. 10, 2019, 5:56 PM), https://www.cnn.com/2016/03/09/politics/donald-trump-islamhates-us/index.html (last updated March 10, 2016). 
9/11 attacks. ${ }^{129}$ Nevertheless, as President, Trump refused to apologize for the statements he made in advocating for the travel ban. ${ }^{130}$

Trump's rhetoric of portraying Islam and Muslims as dangerous and un-American provides a stark contrast to the statements of his presidential predecessors. On September 17, 2001, George W. Bush spoke at the Islamic Center of Washington, D.C., and declared that "[t]he face of terror is not the true faith of Islam. That's not what Islam is all about. Islam is peace. These terrorists don't represent peace. They represent evil and war." 131 In the same speech, Bush further recognized Muslims as legitimate and valuable contributors to U.S. society:

America counts millions of Muslims amongst our citizens, and Muslims make an incredibly valuable contribution to our country. Muslims are doctors, lawyers, law professors, members of the military, entrepreneurs, shopkeepers, moms and dads. And they need to be treated with respect. In our anger and emotion, our fellow Americans must treat each other with respect. 132

Bush then attempted to prevent public backlash against Muslims arising from anger over 9/11, stating that "[t]hose who feel like they can intimidate our fellow citizens to take out their anger don't represent the best of America, they represent the worst of humankind, and they should be ashamed of that kind of behavior."133 At a town hall meeting several months later, he emphasized that "our war is not against Islam, or against faith practiced by the Muslim people. Our war is a war against evil."134

Similarly, in his speech announcing the death of Osama bin Laden, President Obama acknowledged the need for vigilance against the possibility of additional attacks by al-Qaeda but also emphasized that:

[W]e must also reaffirm that the United States is not-and never will be-at war with Islam. I've made clear, just as

129 Cristina Maza, Trump's Speech Causes More Anti-Muslim Hate Crimes than Terrorism, Study Shows, NEwsweek (Nov. 16, 2017, 2:43 PM), https://www.news week.com/trump-speech-anti-muslim-hate-crime-terrorism-study-713905.

130 Jeremy Diamond, Trump Says 'There's No Reason to Apologize' for His Muslim Ban Call, CNN (Apr. 30, 2018, 3:03 PM), https://www.cnn.com/2018/04/30/politics/ trump-immigration-laws/index.html (last updated April 30, 2018).

131 President George Bush, Remarks at the Islamic Center of Washington, D.C. (Sept. 17, 2001) (transcript available through the White House President George W. Bush archives).

132 Id.

133 Id.

134 President George W. Bush, Town Hall Forum on the Economy in California (Jan. 5, 2002) (transcript available through the White House President George W. Bush archives). 
President Bush did shortly after 9/11, that our war is not against Islam. Bin Laden was not a Muslim leader; he was a mass murderer of Muslims. Indeed, al Qaeda has slaughtered scores of Muslims in many countries, including our own. So his demise should be welcomed by all who believe in peace and human dignity. 135

Thus, President Trump's rhetorical approach is a dramatic shift away from the measured, carefully phrased statements of Presidents Bush and Obama, who sought to prevent misdirected violence against U.S. Muslims. Trump's anti-Muslim rhetoric in immigration policy recklessly disregards the harmful effect that such statements have on Muslims within the U.S. ${ }^{136}$ As summarized by Professor Peter Neumann, "the single most important difference between Trump and his predecessors" is how Trump "conflates Islam, immigration, and terrorism."137

\section{B. The Southern Border Wall Project}

On June 16, 2015, while announcing his candidacy for the presidency, Trump blamed immigration from Mexico for some of the crime that occurs in the U.S., declaring that " $[\mathrm{w}]$ hen Mexico sends its people, they're not sending their best. They're not sending you. They're not sending you. They're sending people that have lots of problems, and they're bringing those problems with us. They're bringing drugs. They're bringing crime. They're rapists. And some, I assume, are good people."138 In the same speech, Trump discussed constructing a border wall to stop illegal immigration into the U.S. via Mexico: "I would build a great wall, and nobody builds walls better than me, believe me, and I'll build them very inexpensively, I will build a great, great wall on our southern border. And I will have Mexico pay for that wall."139 Shouts urging construction of the wall became an often-repeated refrain

135 Barack Obama, Barack Obama Announces the Death of Osama bin Laden (May 1, 2011), in Online Speech Bank, AMERICAN RHETORIC, https://www.americanrhetoric.com/ speeches/barackobama/barackobamaosamabinladendeath.htm (last updated Nov. 25, 2018).

136 See Maza, supra note 129.

137 Gilsinan, supra note 4.

138 Donald Trump, Announcement of Presidential Candidacy (June 16, 2015), https://www.cbsnews.com/news/transcript-donald-trump-announces-hispresidential-candidacy. But Professors Jonathan Masur and Eric Posner observe that although "Trump's major argument is that the wall would reduce crime and terrorism[,]" in fact, "the evidence that the wall would have any effect on crime or terrorism is nil" and that "the evidence indicates that illegal immigrants commit crimes at about the same rate as US citizens, which is very low." Jonathan S. Masur \& Eric A. Posner, Cost-Benefit Analysis and the Judicial Role, 85 U. CHI. L. REv. 935, 948 (2018).

139 Trump, supra note 138. 
at Candidate Trump's campaign rallies, ${ }^{140}$ which a commentator characterized by stating that between June 2015 and November 2016, "Trump with frightening regularity use[d] a call and response with his crowds to reinforce his promise to build a wall and vilify immigrants from Mexico and Central and South America." 141 The technique of call and response maintains audience attention by promoting interactivity between speaker and audience. ${ }^{142}$

In subsequent developments, Trump has pointed to international terrorist incidents to bolster his proposal for building a wall along the border between the U.S. and Mexico, although it might be difficult to see any logical connection between the attacks and the idea of a wall along the U.S. southern border. For example, after terrorists attacked a mosque in Egypt on November 24, 2017, Trump used the occasion to tweet a message mentioning the attack and advocating for building the U.S.-Mexico border wall (and maintaining the travel ban). ${ }^{143}$ At least 305 people were killed by the attack on the mosque, which "is largely attended by Sufi Muslims - a form of Islam considered heretical by some conservatives and extremists like the Islamic State group."144 Later, on December 12, 2018, Trump tweeted a message that attempted to connect a shooting perpetrated by a suspected terrorist in Strasbourg, France, to the need for funding to build the U.S. southern border wall.145

140 Jenna Johnson, 'Build that Wall' Has Taken on a Life of Its Own at Donald Trump's Rallies-but He's Still Serious, WASH. Post (Feb. 12, 2016), https://www.washington post.com/news/post-politics/wp/2016/02/12/build-that-wall-has-taken-on-a-life-ofits-own-at-donald-trumps-rallies-but-hes-still-serious.

141 Anu Joshi, Donald Trump's Border Wall-an Annotated Timeline, Huffington Post (Feb. 28, 2017, 5:10 PM), https://www.huffpost.com/entry/donald-trumps-borderwall-an-annotated-timeline_b_58b5f363e4b02f3f81e44d7b (last updated March 1, 2017).

142 Sims Wyeth, 10 Ways Great Speakers Capture People's Attention, Inc. (Mar. 5, 2014), https://www.inc.com/sims-wyeth/how-to-capture-and-hold-audienceattention.html. Wyeth noted the use of call and response in churches but also observed how it had been used in demagoguery: "[T]he world also witnessed the power of audience interaction in the massive rallies of Nazi Germany when Hitler would cry, 'Sieg,' and the soldiers replied, 'Heil,' raising their arms in the Nazi salute." Id.

143 Jill Colvin, Trump Calls for Wall, Travel Ban After Egypt Attack, Boston GloBe (Nov. 24, 2017, 3:08 PM), https://www.bostonglobe.com/news/politics/2017/11/24/ trump-calls-for-wall-travel-ban-after-egypt-attack/nlARZWh1X6wLojZkrCrbVJ/ story.html.

144 Charlene Gubash \& F. Brinley Bruton, Egypt Mosque Attack Leaves At Least 305 Dead in Sinai Peninsula, NBC (Nov. 24, 2017, 7:39 AM), https://www.nbcnews.com/ news/world/egypt-mosque-attack-leaves-dozens-dead-wounded-n823746.

145 Caitlin Oprysko, Trump Uses French Terrorist Attack to Advance Push for Border Wall Funding, Politico (Dec. 12, 2018, 8:35 AM), https://www.politico.com/story/ 2018/12/12/trump-french-terrorist-attack-border-wall-funding-1059169; Allan Smith, Trump Urges Democrats to Fund Border Wall after Mass Shooting in France, NBC 
Regarding the Strasbourg attack, "French prosecutors said the suspect shouted the Arabic phrase 'Allahu Akbar,' meaning 'God is greatest,' at the time of the attack." 146 But the terrorist attacks in Egypt and France had no relation to the presence or absence of a border wall in the U.S. Moreover, the 9/11 terrorists had legally entered the U.S.- one entered with a student visa, while the other eighteen used business or tourist visas. ${ }^{147}$ And since then, terrorist violence within the U.S. has been perpetrated by citizens or other legal residents, rather than by immigrants entering the country illegally. ${ }^{148}$

Thus, Trump's tweeted statements do not logically connect terrorist incidents with his assertion of a need for a U.S. border wall. Instead, he seems to expect that his mere mention of international terrorist incidents and the idea of a border wall should be enough to persuade his Twitter audience that a wall is necessary. Furthermore, a commentator has noted that Trump tends to respond almost immediately-and in strong terms, "at turns combative, sneering, dyspeptic and outraged" - to terrorist attacks conducted by Muslims. ${ }^{149}$

But when acts of terror have been committed by others, such as white nationalists, Trump has either remained silent or allowed days to lapse before responding, and he has used more restrained language in commenting on acts of terror that were not committed by Muslims. ${ }^{150} \mathrm{~A}$ striking example of Trump's refusal to focus criticism on domestic, nonMuslim hate groups involved the "Unite the Right" rally that occurred in Charlottesville, Virginia on August 12, 2017, that drew white nationalists to protest against officials' plan to "remove a statue of the Confederate general Robert E. Lee." 151 During the rally, a white nationalist drove his car into a group of counter-demonstrators, killing one and injuring at least nineteen others. ${ }^{152}$ Trump first "blamed 'many

(Dec. 12, 2018, 9:29 AM), https://www.nbcnews.com/politics/donald-trump/trumpurges-democrats-fund-border-wall-after-mass-shooting-france-n 946906.

146 Saskya Vandoorne et al., French Police Continue Hunt for Strasbourg Gunman, CNN (Dec. 13, 2018, 11:29 AM), https://www.cnn.com/2018/12/12/europe/francestrasbourg-shooting-intl/index.html (last updated Dec. 13, 2018).

147 9/11 Hijackers and Student Visas, FACTCHECK.ORG, https://www.factcheck.org/ 2013/05/911-hijackers-and-student-visas/ (last updated Nov. 24, 2015).

148 Gilsinan, supra note 4.

149 Alex Wagner, Trump's Selective Responses to Terror, ATLANTIC (Jun 6, 2017), https://www.theatlantic.com/politics/archive/2017/06/trumps-selective-responsesto-terror/529218/.

150 Id.

151 Richard Fausset and Alan Feuer, Far-Right Groups Surge Into National View in Charlottesville, N.Y. Times (Aug. 13, 2017), https://www.nytimes.com/2017/08/13/ us/far-right-groups-blaze-into-national-view-in-charlottesville.html.

152 Id. 
sides"' for the violence and later asserted that there were "some very fine people on both sides" of the conflict between the far-right groups and the counter-protestors. ${ }^{153}$

Further, Trump had no comment about a bombing at a mosque in Bloomington, Minnesota in August 2017.154 His absence of comment about that bombing fits a pattern of failure to speak out about several other anti-Muslim incidents in the same year:

Trump's silence on the [Minnesota] attack follows similar periods of quiet after the January shooting at a mosque in Quebec that left six dead, the murder of a Muslim teenager in Virginia and the Finsbury Park mosque attack in London that left one dead, both in June. The White House commented on the last case but Trump never directly addressed it himself on social media or in a statement. ${ }^{155}$

Thus, Trump uses a strategy of depicting terrorists as Muslim outsiders, 156 while downplaying incidents of domestic terrorism perpetrated by non-Muslims or ignoring terrorist incidents when they have targeted Muslim victims.

\section{CONCLUSION}

Since the time of the $9 / 11$ attacks, U.S. presidents have portrayed the nation's conflict against terrorists in terms that evoke a sense of national identity. This paper has examined Bush's statements that were made to prepare the nation for the struggle against the terrorists who committed the 9/11 attacks against the U.S., Obama's declarations that U.S. values must contrast sharply from those of the terrorists, and Trump's assertions that tend to conflate Islam and terrorism in the context of restrictive immigration policy.

153 Rosie Gary, Trump Defends White-Nationalist Protestors: 'Some Very Fine People on Both Sides,' ATlantic (Aug. 15, 2017), https://www.theatlantic.com/politics/archive/ 2017/08/trump-defends-white-nationalist-protesters-some-very-fine-people-onboth-sides/537012.

154 Jack Moore, Trump's Failure to Condemn Minnesota Mosque Attack Stirs Social Media Anger, Newsweek (Aug. 7, 2017, 8:13 PM), https://www.newsweek.com/trumpfailure-condemn-minnesota-mosque-attack-stirs-social-media-anger-647694.

155 Id.

156 Trump's practice of equating Muslims with terrorists seems to tap into a preexisting, anti-Muslim societal bias. Professor Caroline Mala Corbin observes that " $\mathrm{t}] \mathrm{he}$ idea that terrorists are Muslim is pervasive in the United States." Caroline Mala Corbin, Terrorists are Always Muslim but Never White: At the Intersection of Critical Race Theory and Propaganda, 86 FordHAm L. REv. 455, 458 (2017). She further notes that " $\mathrm{t}]$ here is a long history of 'Orientalism,' which positions Arab and Muslims as exotic, uncivilized, dangerous 'others.'” Id. (citing Sahar F. Aziz, Sticks and Stones, the Words That Hurt: Entrenched Stereotypes Eight Years After 9/11, 13 N.Y. CiTy L. REV. 33, 35 (2009)). 
George W. Bush used short, memorable phrases-such as "freedom itself," "wanted, dead or alive," and "War on Terror"- to frame the conflict between the U.S. and terrorists, during and after 9/11. Bush's use of those terms identified the U.S. with the quality of freedom and evoked a sense of nostalgia for the Wild West while declaring war on an abstract emotion. But at the same time, he was careful to avoid vilifying followers of the religion of Islam.

Barack Obama wove rhetorical techniques such as alliteration, metrical arrangement, anaphora, and tricolon into presenting his vision of U.S. values ("the rule of law") in contrast to those of the terrorists ("a hateful ideology"). He also portrayed traditional U.S. adherence to "the rule of law" as demanding the rejection of the use of torture, thus repudiating the Bush administration's policy of torturing terrorism suspects. But Obama approved and adopted Bush's statement that the U.S. was not conducting a war against Islam.

By contrast, Donald Trump has discussed national security and immigration in terms that assert a Muslim threat, while ignoring incidents in which Muslims have been victims of violence-in effect, attempting to construct U.S. identity as non-Muslim, or perhaps even anti-Muslim. Thus, his presidential statements on terrorism seem-at least implicitly-to continue the declaration that he made as a candidate, "I think Islam hates us." Trump has also attempted to use the theme of anti-terrorism to bolster his call for building a border wall between the U.S. and Mexico.

In summary, the rhetorical choices made by each President since 9/11 reflect the values and priorities that he emphasized in depicting the nation's identity while shaping the "War on Terror." 